\title{
Factors affecting employee absenteeism in Nepalese commercial banks
}

\begin{abstract}
The impact of absenteeism on firms or even a nation's economy is enormous, taking account of the costs associated with it. The major objective of the study is to analyze the relationship between job satisfaction, health status, family responsibilities, working condition, employee relation, occupational stress, and transportation problem and employee absenteeism of Nepalese commercial banks and to make suggestions to minimize the level of absenteeism of employees. However the specific objectives of this study are to analyze the perception of employees towards the absenteeism in Nepalese commercial banks, to determine factor affecting employee absenteeism in Nepalese commercial banks, to identify the reasons for absenteeism among employees in Nepalese commercial banks, to examine the relationship between job satisfaction, health status, family responsibilities, working condition, employee relation, occupational stress, transportation problem employee absenteeism in Nepalese commercial banks, to investigate the impact of job satisfaction, health status, family responsibilities, working condition, employee relation, occupational stress, transportation problem on employee absenteeism, to analyze the most important variable affecting employee absenteeism. The study found that job satisfaction is inversely related to absenteeism. The absent from a work situation that is sampling errors, scale inadequacies and the use of different measurement instruments. The psychological model that discusses this is the withdrawal model, which assumes that absenteeism represents individual withdrawal from dissatisfying working conditions. The study support in a negative association between absence and job satisfaction, especially satisfaction with the work itself. Medical-based understanding of absenteeism find support in research that links absenteeism with smoking, problem drinking, low back pain, and migraines Absence ascribed to medical causes is often still, at least in part, voluntary.
\end{abstract}

Keywords : Employee Absenteeism, Job satisfaction, commercial bank

\section{Introduction}

Absenteeism has been defined as the non-attendance of employees for scheduled work (Chadwick, 1982). Defined absenteeism as any failure of an employee to report for or remain at work as scheduled regardless of reason. From a business perspective, the employee is absent and is simply not available to perform his or her job resulting into higher cost to the organization. Absenteeism is a common problem in many industrial units, small or big, private or government. The high rate of absenteeism is at times due to lack of commitment to work. Absenteeism results in dislocation of work increase in labor costs, reduction in productivity and if unchecked, it causes an increase in indiscipline. Although some amount of absent will 
always be inevitable, most of it can be avoided. If such absences become excessive, they can have a serious adverse impact on a business operation and ultimately, its profitability. As absenteeism is characterized as employee absence from scheduled work, which differs from other types of absence (public holidays and annual leave) (Mani \& Jaisingh, 2014).

Employee absenteeism is a costly yet poorly understood organizational phenomenon (Martocchio \& Harrison, 1993). The consequences of employee absenteeism are widespread and consist of direct and indirect effects. For instance higher costs are a result of absenteeism, which can be caused both directly as well as indirectly. Direct costs of sickness absence to employers include statutory sick pay, expense of covering absence with temporary staff and lost production. Indirect costs, such as low morale among staff covering for those absent because of sickness and lower customer satisfaction, are difficult to measure, while they also influence the overall levels of output (Leaker, 2008). Other effects associated with absenteeism are disruption of the work flow and reduction in product quality (Klein, 1986). Leaker (2008) estimated in 2008 for the Confederation of Business Industry that the United Kingdom had approximately lost $£ 19.2$ billion in 2007 to direct and indirect costs of employee absenteeism.

The impact of absenteeism on firms or even a nation's economy is enormous, taking account of the costs associated with it. A better understanding of the determinants of absenteeism can be valuable for firms and policymakers (Störmer and Fahr, 2010).

For this reason governments are intensively researching better ways of handling with this problem. This resulted for example in a parliamentary inquiry in the Netherlands in 1993. The Dutch absence rate had a long history of high sickness absence and work disability rates compared with other European countries (Geurts, 2000).

In Nepalese workplaces, most prominent employee's related issues are lack of corporate culture, lack of mechanism to implement employee legislations, low degree of integration and coordination of different business functions, lack of performance based system, low level of pay and rising absenteeism (Adhikari et al., 2010).

Absenteeism is most complicated situation as expressed by many, both at Ministry of Health and at DHO level. Even when position is filled, absenteeism from work is widely reported during the field work in 10 BNMT districts. A study in 23 district hospital recorded that while overall presence of staff for full 12 month were over $85 \%$, but doctors were present only $56 \%$ of their time in the district (Moga, 2011).

Gautam (2011) investigated the trends of HRM practices in Nepalese organization. The findings of the study revealed that Nepalese organizations prefer experienced and mid-career human capital as compared to fresh graduates and undergraduates. Such practice of hiring experienced personnel not only saves time of the organization, but also saves cost on training and reduces absenteeism rate. 
The above discussion showed that the study dealing employee absenteeism is of greater significance. Though there are these findings in the context of different countries, no such findings using more recent data exist in the context of Nepal. Hence, this study focuses on the determinants of employee absenteeism in the context of Nepalese commercial banks.

\section{Statement of the problem}

Work attendance and absenteeism are linked to many factors, with the major, though not sole determinant, being disease-related incapacity. Work attendance is generally considered to reflect the "complex person-work-enterprise-society relationship" (LaDou, 2003).

Many individual factors are linked to absenteeism such as past absence history, education, personality and the abuse of drugs and alcohol. The largest single component of sickness absenteeism is associated with genuine incapacity attributable to illness and injury. Moreover, health status is only a minor contributor although this depends upon definition. Health status (by self-report) was not found to influence absenteeism significantly (Brook \& Price, 1989).

Chapagai (2011) examined the relationship between employees' participation and job satisfaction in Nepal for which four Nepalese commercial banks were chosen. The result showed that there is the strong positive relationship between employee participation practices and job satisfaction in Nepalese banking sector. Increased employee participation makes a positive effect on job satisfaction of Nepalese banking employees, lowering down the employees' absenteeism rate and intention to quit the job.

Generally, the commercial bank is facing a tight competition all over the world. So the bank should have to take necessary steps and this also helps the management to know about the employee's basic needs which are not fulfilled and what the employee's expectations.

Though there are above mentioned empirical evidences in the context of other countries and in Nepal, no such evidences using more recent data exist in the context of Nepal. This study therefore deals with the following issues in the context of Nepalese commercial banks.Thus, this study deals with the following issue:

- What is the perception of employee on job satisfaction, health status, family responsibilities, working condition, employee relation, occupational stress, transportation problem and absenteeism?

- Which factor mostly affect absenteeism in Nepalese commercial banks?

- Which factor among job satisfaction, health status, family responsibilities, working condition, employee relation, occupational stress, transportation problem play important role in absenteeism? 


\section{Objectives of the study}

The major objective of this study is to identify the factors affecting employee absenteeism in Nepalese commercial banks. The specific objectives of the study are as follows:

- To determine the key factors that are responsible for employee absenteeism in the Nepalese commercial banks in Nepal.

- To examine the relationship among job satisfaction, health status, family responsibilities, working condition, employee relation, occupational stress, transportation, employee absenteeism in Nepalese commercial banks.

- To investigate the impact of job satisfaction, health status, family responsibilities, working condition, employee relation, occupational stress, transportation problem on employee absenteeism.

\section{Review literature}

The several empirical studies have been carried out on factors affecting employee absenteeism.

Yahayaet (2009) explained the causes of occupational stress and its implication on job satisfaction and absenteeism within the organization. Pearson product moment correlation to find out correlations and multiple linear regression technique were used to find out effect between variables. The study revealed that factor such as external environment contributes to the occupational stress. This external factor is beyond the control of the organization. The result also showed that occupational stress does not have direct effect on intention to leave and absenteeism but have direct negative effect on job satisfaction. By reducing stress companies can reduce the level of intention to leave and absenteeism.

Meneze (2005) investigated the impact of stress on employee productivity, performance and turnover; an important managerial issue. Field study was conducted with questionnaire as the primary data collection instrument. Data was analyzed using statistical techniques with SPSS Version 16. The factors affecting stress were identified as personal issues, lack of administrator support, lack of acceptance for work done, low span over work environment, unpredictability in work environment and inadequate monetary reward. Analysis showed immense support for negative relationship between stress and job performance greatly affected career change over and job satisfaction, errors in treatment, knowledge. The results showed that with every unit; increase in personal dilemmas, decrease in financial reward, decrease in influence over work environment, decrease in supervisor support, there would be decrease in job performance.

Givord (2002) assessed the impact of working conditions on absenteeism. This paper explores how bad working conditions impact absenteeism at work through their effect on health. The study's contribution is two-folded. First, the study developed a model of labor supply which accounts for the evolution of health status. Second, estimated the effect of working irregular 
schedules on sickness absence for male manual workers. To reduce the selectivity bias, the study used a propensity score matching method and test its robustness with a "selection on unobservable" specification. The study found that working irregular schedules has a significant impact on sickness absence, the sign and the extent of which crucially depend on age.

McHugh (2002) investigated about the absenteeism from work. The study was carried out between August 1999 and March 2000. A multi-method approach was used to gather data from participating organizations. The latter is likely to foster the creation of more healthy work organizations which are well placed to deal effectively with the challenges presented by hostile and turbulent operating environments.

Vaananenet (2003) examined on job characteristics, physical and psychological symptoms, and social support as antecedents of sickness absence among men and women in the private industrial sector. The purpose of this study was to find out psycho social antecedents of sickness absenteeism in the private industrial sector. The effects of job characteristics (job autonomy and job complexity), physical and psychological symptoms, and social support (from coworkers and supervisors) on sickness absenteeism were investigated. A questionnaire survey on the working conditions and health of the workers was carried out in 1996. The study found that psychosocial factors are associated with subsequent sickness absence, and that the associations are partly gender-specific.

Working conditions can have both negative and positive effects on employees' job attitudes and reactions to their jobs. Work environment includes both physical and psychological, which encompass the lighting, temperature, noise, office arrangement, peer relationships, warmth, perceived rewards, supervisory style, job satisfaction, low morale, sick leave entitlement, inadequate remuneration and poor working conditions (Hittet, 2006).

\section{Conceptual framework}

Conceptual framework is developed to link a relationship between independent variables and dependent variables. This study focuses on factors affecting employee absenteeism in Nepalese commercial banks. This study has taken employee absenteeism of Nepalese commercial bank as dependent variable, whereas job satisfaction, health status, family responsibilities, working condition, employee relation, occupational stress and transportation problem as independent variables in order to measure the factors affecting employee absenteeism of Nepalese commercial banks. Based on these, the relationships between different dimension of employee absenteeism and its determinants are constructed to form the study framework for the present study, as shown in figure 1. 
Figure 1: Schematic diagram on factors affecting employee absenteeism in Nepalese commercial banks job satisfaction, health status,

\section{Independent Variable}

- Job Satisfaction

- Health Status

- Family Responsibilities

- Working Condition

- Employee Relation

- Occupational Stress

\section{Hypotheses}

Based on the conceptual framework on Figure 1 hypotheses have been formulated as following:

$\mathrm{H}_{1}$ : There is the negative relationship between employee absenteeism and job satisfaction.

$\mathrm{H}_{2}$ : $\quad$ There is the negative relationship between employee absenteeism and health status.

$\mathrm{H}_{3}$ : There is the positive relationship between employee absenteeism and family responsibilities.

$\mathrm{H}_{4}$ : There is the negative relationship between employee absenteeism and working condition.

$\mathrm{H}_{5}$ : There is the negative relationship between employee absenteeism and employee relation.

$\mathrm{H}_{6}$ : There is positive relationship between occupational stresses and employee absenteeism.

$\mathrm{H}_{7}$ : There is the positive relationship between employee absenteeism and transportation problem

\section{Research methodology}

Research methodology describes the method and process applied in the entire aspects of study and helps to resolve the systematic problems. Research methodology is used to collect information and data and sets out overall plan associated with a study. It also provides a basic framework on which the study is based.

This study employs descriptive research design and causal comparative research design to deals with the fundamental issues associated with the factors affecting employee absenteeism in Nepalese commercial banks. The descriptive research design has been adopted for fact finding and searching adequate information about the factors affecting employee absenteeism. This study has employed causal-comparative research design to determine the cause and effect of independent variables. 
The study is based on primary data were used to extract the information from the employees regarding job satisfaction, health status, family responsibilities, working condition, employee relation, occupational stress and transportation problem and its impact on absenteeism in Nepalese commercial banks. This study includes 189 respondents from 18 commercial banks within Kathmandu valley. The level of employees taken as respondents in the study falls under assistant level, officer level, manager level and senior manager level. For the analysis of factors affecting absenteeism in Nepalese commercial banks, 200 questionnaires were distributed to the employees of 18 commercial banks within Kathmandu valley and 189 were collected. For data collection, one of the non-probabilistic techniques i.e. convenience has been used. Convenience sampling is one of the type of non-probability based on which they think would be appropriate for the study. Table 2 shows the list of sample commercial banks selected for the study and number of respondents.

Table 1: Number of Commercial Banks Selected and Number of Respondents

\begin{tabular}{|c|l|c|}
\hline S.No. & Name of the commercial banks & Number of respondents \\
\hline 1 & Kumari Bank Limited & 11 \\
\hline 2 & Siddhartha Bank Limited & 13 \\
\hline 3 & RastriyaBanijya Bank Limited & 15 \\
\hline 4 & Nepal Bank Limited & 18 \\
\hline 5 & Agriculture Development Bank Limited & 12 \\
\hline 6 & Nepal Investment Bank Limited & 8 \\
\hline 7 & Himalayan Bank Limited & 13 \\
\hline 8 & Nepal SBI Bank Limited & 10 \\
\hline 9 & Everest Bank Limited & 7 \\
\hline 10 & Global IME Bank Limited & 5 \\
\hline 11 & Sunrise Bank Limited & 11 \\
\hline 12 & NMB Bank Limited & 13 \\
\hline 13 & NIC Asia Bank Limited & 9 \\
\hline 14 & Machhapuchhre Bank Limited & 7 \\
\hline 15 & Century Bank Limited & 7 \\
\hline 16 & Sanima Bank Limited & 6 \\
\hline 17 & Laxmi Bank Limited & 7 \\
\hline 18 & Janata Bank Nepal Limited & $\mathbf{1 8 9}$ \\
\hline \multicolumn{2}{|l}{ Total number of respondents } & \\
\hline
\end{tabular}

The structural questionnaire is designed to collect information on the factors affecting employee absenteeism in Nepalese commercial banks. First part of questionnaire deals with the demographic information. This part of questionnaire is used for descriptive analysis of the respondents. Similarly, second part of the questionnaire is designed to analyze the factors affecting employee absenteeism. There are 5 statements that characterize each factor that affects organizational performance. Each statement was measured on Likert scale. 5-point Likert scale has been used for the survey of which $1=$ strongly disagree, $2=$ disagree, $3=$ neutral, 
$4=$ agree and $5=$ strongly agree. The level of agreements and disagreements of each statement were used to measure the perception of the respondents about given statement.

The questionnaire in second part consists of various statements of the job satisfaction, health status, family responsibilities, working condition, employee relation, occupational stress and transportation problem by exception on employee absenteeism. These variables were used to determine the factors affecting employee absenteeism. This design was adopted to ascertain and understand the direction, magnitude and forms of observed relationship between different factors and employee attendance. The reliability of the data has been tested by calculating Cronbach's alpha.

Primary are analyzed using the software SPSS 23 version. In the beginning, comprehensive file is created. Then, variable and their labels are defined and its values are inserted. The descriptive statistics contains mean, standard deviation, minimum and maximum values of variables which used to explain the characteristics of sample firms. The regression analysis is used to find out the influence of independent variable over dependent variable solely and combined with other variables. It explains the different statistical tests of significance for validation of model like t-test, F-test, detection of and linear regression analysis. All models are tested for individual effects by running F-test using statistical package for social science (SPSS 23).

Total responses collected from the respondents are coded and tabulated into SPSS worksheet. The function of SPSS is to analyze the result of the questionnaire and then helps to interpret the findings. The various tools such as frequencies, descriptive statistics, and casual comparative and reliability analysis (Cronbach's alpha) are applied to derive the result. Further, p-value is used to check the level of significance of the different statements of employee absenteeism.

The econometric models employed in this study tries to determine relationship between the factors affecting employee absenteeism and its independent variables. The least square regression model is used in this study to examine the empirical relationship between the effects of employee absenteeism on its influencing factors of Nepalese commercial banks. Thus, the following model equation is designed to test the hypothesis. From the conceptual framework the function of dependent variables (i.e. employee absenteeism) takes the following form:

Employee Absenteeism = $f($ JS, HS, FR, WC, ER, OS and TP $)$

More specifically, the given model has been segmented into the following models:

\section{Model}

$\mathrm{EA}=\beta_{0}+\beta_{1} \mathrm{JS}+\beta_{2} \mathrm{HS}+\beta_{3} \mathrm{FR}+\beta_{4} \mathrm{WC}+\beta_{5} \mathrm{ER}+\beta 6 \mathrm{OS}+\beta_{7} \mathrm{TP}+\mathrm{ei}$ 
In the above regression model, the dependent variable is the employee absenteeism indicated by EA. The impact of charisma, inspirational motivation, intellectual stimulation, constructive reward and management by exception on organizational performance is tested.

Where,

$\mathrm{EA}=$ Employee performance

JS = Job Satisfaction

HS = Health Status

FR $=$ Family Responsibilities

$\mathrm{WC}=$ Working Condition

$\mathrm{ER}=$ Employee Relation

OS = Occupational Stress

TP $=$ Transportation Problem

$\mathrm{e}_{\mathrm{i}}=$ Error term

$\beta_{0}$ is the constant term and $\beta_{1^{\prime}}, \beta_{2^{\prime}} \beta_{3^{\prime}} \beta_{4^{\prime}}, \beta_{5,} \beta_{6}$ and $\beta_{7}$ are the coefficients of variables.

Validity refers to the degree to which a measure accurately represents what it is supposed to measure. It also determines the truthfulness of findings. It determines the accuracy of a measure and a measurement is valid when it measures and performs the functions that it supports to perform. On the other hand, reliability is the degree to which an assessment tool produces stable and consistent results. In another word, reliability is the degree to which the observed variable measures the true value and is error free. The reliability is measured and conformed by testing both consistency and truthfulness of the respondents' response in primary data.

Cronbach's alpha is a statistic tool generally used to measure the internal consistency or reliability. It has been used to test the validity and reliability of the primary data for determining internal consistency among the various proxies of employee absenteeism such as job satisfaction, health status, family responsibilities, working condition, employee relation, occupational stress and transportation problem by exception to measure the reliability of the different categories. Table 3.3 shows the validity and reliability of the questions of the study. It is a function of the number of test items and the average inter correlation among the items. As a general rule, Cronbach alpha's $a<0.5$ is unacceptable, $0.5 \leq a<0.6$ is poor, similarly Cronbach alpha's $0.6 \leq a<0.7$ is questionable, $0.7 \leq a<0.8$ is acceptable, $0.8 \leq a<0.9$ is good and $0.9 \leq \alpha$ is excellent. Similarly, Coefficient of Cronbach Alpha greater than or equal to 0.7 considered acceptable and is a good indication of construct reliability. Table 3 represents the coefficient of Cronbach's alpha for all the primary data. 
Table 2: Coefficient of Cronbach's Alpha Reliability Statistics

\begin{tabular}{|l|l|l|l|}
\hline S.N & Variables & Cronbach's Alpha & No. of Questions \\
\hline 1 & Job Satisfaction & 0.725 & 6 \\
\hline 2 & Health Status & 0.573 & 5 \\
\hline 3 & Working Condition & 0.573 & 5 \\
\hline 4 & Occupational Stress & 0.638 & 5 \\
\hline 5 & Transportation Problem & 0.564 & 5 \\
\hline 6 & Family Responsibility & 0.773 & 5 \\
\hline 7 & Employee Relation & 0.732 & 5 \\
\hline 8 & Employee Absenteeism & 0.698 & 7 \\
\hline & Total & 0.934 & 43 \\
\hline
\end{tabular}

Source: Response on Survey Questionnaire

According to the table Reliability test for all the component of questionnaire regarding the factors affecting employee absenteeism in Nepalese commercial banks were computed through SPSS. Here, in the table 3 Cronbach's alpha for Job Satisfaction, Family Responsibility and Employee Relation are $0.725,0.773$ and 0.732 respectively which shows that internal consistency of variable are acceptable. Similarly, Occupational stress and Employee absenteeism have 0.638 and 0.698 Cronbach's alpha which revels Questionable internal consistency. Finally Health Status, Working Condition and Transportation Problem have 0.573, 0.573 and 0.564 which Cronbach's alpha are approximately 6 so they are also questionable internal consistency. Which reveals that there consists of internal consistency and the data is reliable and valid for further process. The Coefficient Cronbach's alpha of the data is 0.934 also shows that 93.40 percent of the data taken for the study is reliable and remaining 6.60 percent of data is error. The value of alpha is partially dependent on the number of items in the scale.

\section{Descriptive Statistics}

Table 3 shows the overall mean and Standard deviation of the variables.

Table 3: Descriptive Statistics of Variables

\begin{tabular}{|c|c|c|}
\hline Variables & Mean & Std. Deviation \\
\hline Job Satisfaction & 3.75 & .91 \\
\hline Health Status & 3.86 & .85 \\
\hline Family Responsibility & 3.75 & .76 \\
\hline Working Condition & 3.69 & .87 \\
\hline Occupational Stress & 3.62 & .82 \\
\hline Transportation Problem & 3.45 & .95 \\
\hline Employee Relation & 3.77 & .76 \\
\hline Employee Absenteeism & 3.51 & .78 \\
\hline
\end{tabular}

Table 3 highlights all the constructs report men value greater than 3 and standard deviation below 0.1. This means the constructs were well responded by the respondents and having well for further analysis purpose. 


\section{Correlation Analysis}

Correlation analysis tests the relation between two variables. It is explained in Tabl4.

Table 4: Correlation Matrix

\begin{tabular}{|c|c|c|}
\hline Correlation & & Employee Absenteeism \\
\hline \multirow{2}{*}{ Job Satisfaction } & Correlation & -.29 \\
\cline { 2 - 3 } & Sig & 0.00 \\
\hline \multirow{2}{*}{ Health Status } & Correlation & -.38 \\
\cline { 2 - 3 } & Sig & 0.00 \\
\hline \multirow{2}{*}{ Family Responsibility } & Correlation & 0.47 \\
\cline { 2 - 3 } & Sig & 0.00 \\
\hline \multirow{2}{*}{ Working Condition } & Correlation & -.54 \\
\cline { 2 - 3 } & Sig & 0.00 \\
\hline \multirow{2}{*}{ Employee Relation } & Correlation & -.43 \\
\cline { 2 - 3 } & Sig & 0.00 \\
\hline \multirow{2}{*}{ Occupational Stress } & Correlation & 0.45 \\
\cline { 2 - 3 } & Sig & 0.00 \\
\hline \multirow{2}{*}{ Transportation Problem } & Correlation & .47 \\
\cline { 2 - 3 } & Sig & 0.00 \\
\hline
\end{tabular}

Table 4 shows the weak correlation between job satisfaction and employee absenteeism in the negative direction ( $r=-.29)$ (Levin \& Fox, 2006), which is sig. at $5 \%$ level of significance. So, $\mathrm{H} 1$ is accepted.

Health status is negatively correlated with employee absenteeism moderately ( $\mathrm{r}=-.38)$ (Levin \& Fox, 2006), which is sig. at 5\% percent level of significant. So, H2 is accepted.

Family responsibility is moderately correlated with employee absenteeism in the positive direction ( $r=0.47)$ (Levin \& Fox, 2006), which is sig. at 5\% percent level of significant. So, H3 is accepted.

Working condition is moderately correlated with employee absenteeism in the negative direction ( $r=-.54)$ (Levin \& Fox, 2006), which is sig. at 5\% percent level of significant. So, H4 is accepted.

Employee relation is moderately correlated with employee absenteeism in the negative direction ( $r=-.43)$ (Levin \& Fox, 2006), which is sig. at 5\% percent level of significant. So, H5 is accepted. 
Occupational stress is moderately correlated with employee absenteeism in the positive direction ( $\mathrm{r}=0.45)$ (Levin \& Fox, 2006), which is sig. at 5\% percent level of significant. So, H6 is accepted.

Transportation problem is moderately correlated with employee absenteeism in the positive direction ( $\mathrm{r}=0.47)$ (Levin \& Fox, 2006), which is sig. at $5 \%$ percent level of significant. So, H7 is accepted.

\section{Conclusions}

In the context of Nepal, the study revealed that the employee participation is positively related to job satisfaction, employee fairness perception and organizational commitment. The result is similar to the findings of (Pandey, 2015). Which shows the lowering the employee absenteeism rate. The study also indicates employees with various years of job experience have significant differences in job satisfaction. Out of various factors job security, pay, promotion potentials, relationship with co-workers and supervisors are top most influencing factors to job satisfaction from high to low magnitude respectively. The study shows that occupational stress, transportation problem and family responsibilities have positive and significant impact on employee absenteeism of Nepalese commercial banks. However the regression analysis revealed job satisfaction, health status, working condition and employee relation that for Nepalese commercial banks. The study concludes that job satisfaction is the most dominant factors that influence employee absenteeism in Nepalese commercial banks.

\section{Reference}

Adhikari, A. (2009). Factors Affecting Employee Attrition: A Multiple Regression Approach. Journal of Management Research, 8(5), 38-47.

Adhikari, D.R. \& Gautam, D.K. (2011). Employees' Commitment and Organizational Performance in Nepal: A Typological Framework. SEBON Journal, 5(1), 1-17.

Afsa, C., \& Givord, P. (2002). The Impact of Working Conditions on Absenteeism. Work, 4(2), 60-72.

Aisha, A., Hardjomidjojo, P., \& Yassierli, A. (2013). Effects of Working Ability, Working Condition, Motivation and Incentive on Employees' Multi-Dimensional Productivity. International Journal of Innovation, Management and Technology, 4(6), 1-5.

Avey, J. B., Patera, J. L., \& West, B. J. (2006). The Implications of Positive Psychological Capital on Employee Absenteeism. Journal of Leadership and Organizational Studies, 13(2), 4260.

Baniya, L.B. (2004). Human Resource Development Practice in Nepalese Business Organizations: A Case Study of Manufacturing Enterprises in Pokhara. Journal of Personnel Review, 39(5), 574-599.

Barham, C. \& Begum, N. (2005). Sickness Absence from Work in the UK, Office of National Statistics, 149-158.

Barmby, T. A., Ercolani, M. G., \& Treble, J. G. (2002). Sickness Absence: an International Comparison. The Economic Journal, 112(480), 315-331. 
Barmby, T., Ercolani, M. \& Treble, J. G. (2000). Sickness Absence: An International Comparison. Unpublished Thesis. University of South Africa.

Begum, S., \& Sen, B. (2000). Not Quite, Not Enough: Financial Allocation and the Distribution of Resources in the Health Sector. Bangladesh Institute of Development Studies.33(1), $110-220$.

Behrend, H. (1959). Voluntary Absence from Work, International Labour Review, 19(2), 109135.

Benavides, F.G., Benach,J., Diez-Roux, A. V., \& Roman, C. (2000). How do Types of Employment Relate to Health Indicators? Findings from the Second European Survey on Working Conditions. Journal of Epidemiology and Community Health, 54(7), 494-501.

Bennett, H. (2002). Employee Commitment: the Key to Absence Management in Local Government?. Leadership and Organization Development Journal, 23(8), 430-441.

Berggren, C. (1993). Lean Production - the End of History? Work, Employment and Society, 7(2), 163-188.

Bista, P. (2016). Job Satisfaction Among Employees of Commercial Banks in Nepal. Proceedings of the Australia-Middle East Conference on Business and Social Sciences, 4(2), 163-177.

Block, J., \& Block, J. H. (2014). The Role of Ego-control and Ego-resiliency in the Organization of Behavior. In Development of Cognition, Affect, and Social Relations, 49-112.

Boles, M., Pelletier, B. \& Lynch, W. (2004). The Relationship between Health Risks and Work Productivity. Journal of Occupational and Environment Medicine, 46(7), 737-745.

Borda, R. G., \& Norman, I. J. (1997). Factors Influencing Turnover and Absence of Nurses: a Research Review. International Journal of Nursing Studies, 34(6), 385-394.

Brooke Jr, P. P., \& Price, J. L. (1989). The Determinants of Employee Absenteeism: An Empirical Test of a Causal Model. Journal of Occupational Psychology, 62(1), 1-19.

Brown, S., F. Fakhfakh, J. \& Sessions, G. (1999). Absenteeism and Employee Sharing: An Empirical Analysis Based on French Panel Data, 1981-1991. ILR Review, 52(2), 234-251.

Camp, S. D., \& Lambert, E. G. (2006). The Influence of Organizational Incentives on Absenteeism: Sick-leave use Among Correctional Workers. Criminal Justice Policy Review, 17(2), 144-172.

Cartwright, D. \& Zander, A. (1968). Group Dynamics (3rd ed.). Oxford, England: Harper Row.

Cascio, W. F. (2006). Managing Human Resources: Productivity, Quality of Work Life, Profits 7th Edition Tata McGraw-Hill. Abnormal and Social Psychology, 62, 401-407.

Celik, M. (2011). A Theoretical Approach to the Job Satisfaction. Polish Journal of Management Studies, 4, 7-14.

Chadwick-Jones, J. J. K., Nicholson, N., \& Brown, C. (1982). Social Psychology of Absenteeism. Social Psychology of Absenteeism. 25(3), 10-19.

Chapagai, R. R. (2011). Impact of Employee Participation on Job Satisfaction in Nepalese Commercial Bank. PYC Nepal Journal of Management, 4(1), 40-51. 
Chaudhary, N., \& Sharma, B. (2012). Impact of Employee Motivation on Performance (Productivity) in Private Organization. International Journal of Business Trends and Technology, 2(4), 29-35.

Chen, L.H. (2008). Job Satisfaction Among Information System (IS) Personnel. Computers and Human Behaviour, 24(1), 105-118.

Cholli C., Sreeraj P. \& Pandey S. (2017). To Study the Factors of Absenteeism in Hospitality Sector in India. Imperial Journal of Interdisciplinary Research, 3(2), 524-533

Bermingham, C. (2013). Employee's Understanding of Workplace Absenteeism and the Investigation of Stress as a Contributing Factor. Interntional Journal of Innovation, Management, 50(7), 29-35.

Cohen, A., \& Golan, R. (2007). Predicting Absenteeism and Turnover Intentions by Past Absenteeism and Work Attitudes: An Empirical Examination of Female Employees in Long Term Nursing Care Facilities. Career Development International, 12(5), 416432.

Crossley, T. F., \& Kennedy, S. (2002). The Reliability of Self-assessed Health Status. Journal of Health Economics, 21(4), 643-658.

Dalton, D. R., \& Mesch, D. J. (1991). On the Extent and Reduction of Avoidable Absenteeism: An Assessment of Absence Policy Provisions. Journal of Applied Psychology, 76(6), 810817.

De Boer, E. M., Bakker, A. B., Syroit, J. E., \& Schaufeli, W. B. (2002). Unfairness at Work as a Predictor of Absenteeism. Journal of Organizational Behavior: The International Journal of Industrial, Occupational and Organizational Psychology and Behavior, 23(2), 181-197.

De Klerk, M., \& Mostert, K. (2010). Work-home Interference: Examining Socio-Demographic Predictors in the South African context. SA Journal of Human Resource Management, 8(1), 10.

De Meuse, K. P., Bergmann, T. J., Vanderheiden, P. A., \& Roraff, C. E. (2004). New Evidence Regarding Organizational Downsizing and a Firm's Financial Performance: A Longterm Analysis. Journal of Managerial Issues, 16(2), 155-177.

Demir, K., \& Karabeyoglu, Y. A. (2016). Factors Associated with Absenteeism in High Schools. Eurasian Journal of Educational Research, 62(62), 16(62).

Drakopoulos, S. A., \& Grimani, K. (2013). Injury-related Absenteeism and Job Satisfaction: Insights from Greek and UK Data. The International Journal of Human Resource Management, 24(18), 3496-3511.

Ekinci, Y., \& Riley, M. (2000). The Application of the Guttman Scaling Procedure in the Measurement of Consumer Behaviour: A Marketing Myopia. Journal of Travel and Tourism Marketing, 8(4), 25-42.

El Shikieri, A. B., \& Musa, H. A. (2012). Factors Associated with Occupational Stress and Their Effects on Organizational Performance in a Sudanese University. Creative Education, 3(01), 134-144.

Enterline, P.E. (1964). Sick Absence for Men and Women by Marital Status, Archives of Environmental Health, 8(3), 466-470. 
Evans, A, Walter, M. \& Palmer, S. (2002). From Absence to Attendance. (2nd Ed). London, UK: Cromwell Press.

Fishman, A. (1996). Employers Differ on Best Way to Combat Absenteeism. Inside Tucson Business, 6(5), 19.

Fitzgibbons, D.E. (1992). A Critical Reexamination of Employee Absence: The Impact of Relational Contracting, the Negotiated Order, and the Employment Relationship, Research in Personnel and Human Resources Management, 10, 73-120.

Gangai, K. N. (2014). Absenteeism at Workplace: what are the Factors Influencing to it? International Journal of Organizational Behaviour and Management Perspectives, 3(4), 1282-1289

Gellatly, I. R. (1995). Individual and Group Determinants of Employee Absenteeism: Test of a Causal Model. Journal of Organizational Behavior, 16(5), 469-485.

Geurts, S., Kompier, M \& Grundemann, R. (2000) Curing the Dutch Disease? Sickness Absence and Work Disability in the Netherlands, International Social Security Review, 53(4), 79103.

Gibson, J. J. (1976). The Myth of Passive Perception: a Reply to Richards. Philosophy and Phenomenological Research, 37(2), 234-238.

Gibson, R. O. (1966). Toward a Conceptualization of Absence Behavior of Personnel in Organization. Administrative Science Quarterly, 11(1), 107-133.

Gimeno, D., Benavides, F. G., Benach, J., \& Amick, B. C. (2004). Distribution of Sickness Absence in the European Union Countries. Occupational and Environmental Medicine, 61(10), 867-869.

Glaser, B. M. (1976). Productivity Gains Through Worklife Improvement. New York : The Psychological Corporation, 2, 34-43.

Graça, L. (1996). Um Problem de Saúdepública: O Absentismporincapacidade de Trabalho. Revista Portuguesa de Saúde Pública, 14(3), 5-19.

Greenhaus, J. H., \& Beutell, N. J. (1985). Sources of Conflict between Work and Family Roles. Academy of Management Review, 10(1), 76-88.

Hacket, R. D. (1989). Work Attitudes and Employee Absenteeism: A Synthesis of the literature. Journal of Occupational Psychology, 62(3), 235-248.

Hackett, R. D. (1990). Age, Tenure, and Employee Absenteeism. Human Relations, 43(7), 601-619.

Hamilton-Atwell, A. (2003). Absenteeism: Managing it for Organizational Improvement. Management Today, 18(10), 56-61.

Harrison, D. A., \& Martocchio, J. J. (1998). Time for Absenteeism: A 20-year Review of Origins, Offshoots, and Outcomes. Journal of Management, 24(3), 305-350.

Hill, M. (1967). Mio stays home? New Society, 9, 459-460.

Hitt, M. A., Miller, C. C., \& Colella, A. (2006). Organizational Behavior a Strategic Approach. John Wiley and Sons.

Ilgen, D. R., \& Höllenback, J. H. (1977). The Role of Job Satisfaction in Absence Behavior. Organizational Behavior and Human Performance, 19(1), 148-161. 
Ivancevich, J.M. \& Matteson, M. T. (2004). Absenteeism Among Women Workers in Industry. Organizational behaviour and Management. 2, 222-248.

Jehn, K. A., Rupert, J., \& Nauta, A. (2006). The Effects of Conflict Asymmetry on Mediation Outcomes: Satisfaction, Work Motivation and Absenteeism. International Journal of Conflict Management, 17(2), 96-109.

Jensen, S., \& McIntosh, J. (2007). Absenteeism in the Workplace: Results from Danish Sample Survey Data. Empirical Economics, 32(1), 125-139.

Jex S. M. (2002). Organizational Psychology:a Scientist-Practitioner Approach. New York: John Wiley and Sons. 4(2). 63-75.

Johns, G. \& Nicholson, N. (1982). The Meaning of Absence: New Strategies for Theory and Research, Research in Organizational Behaviour, 4, 127-172.

Kandemir, A., \& Sahin, B. (2017). The Level and Cost Burden of Absenteeism Among Health Care Professionals. IşletmeBilimiDergisi, 5(2), 1-23.

Kashi R. (2017). An Analysis of Occupational Stress and Its Impact on Employees. International Journal of Scientific Research and Management, 5(11), 7545-7559.

Kehinde, A. O. (2011). Impact of Job Satisfaction on Absenteeism: A Correlative study. European Journal of Humanities and Social Sciences, 1(1), 25-49.

Keller, B. (2008). Districts Experiment with Cutting Down on Teacher Absence. Education Week, 27(35), 1-13.

Kelly, L. (1992). Attendance Management: An Issue of the „90s. Work Life Report, 8(5), 12-14.

Klein, W. (1986). Missed Work and Lost Hours. Monthly Labor Review Bureau of Labor Statistics, 109, 26-30.

Knox, J. B. (1962). Absenteeism and Turnover in an Argentine Factory. American Labor Review, 19 (85), 48-61

Lama, S. (2013). Association between Work Motivation and Job Satisfaction of College Teachers. Journal of Administration and Management Review, 24(2), 44-55.

Lazarus, R. S. (1966). Psychological Stress and the Coping Process. New York, NY, US: McGraw-Hill.

Leaker, D. (2008) Sickness Absence from Work in the UK, Office of National Statistics, 2(11), 18-22.

Levin, J., \& Fox, J.A. (2006). Elementary statistics in social research (1st impression). Delhi, Patparganj: Dorling Kindersley (India) Pvt. Ltd., licensees of Pearson Education in South Asia.

Linn, B.S. \& Linn, M.W. (1980) Objective and Self-assessed Health in the Old and Very old, Social Science and Medicine. Part A: Medical Psychology and Medical Sociology, 14(4), 311315.

Long, L., \& Perry, J. L. (1985). Economic and Occupational Causes of Transit Operator Absenteeism: A Review of Research. Transport Reviews, 5(3), 247-267.

Lusinyan, L. \& Bonato, L. (2007). Work Absence in Europe. IMF Staff Papers, 54(3), 475-538. 
Maher, M. (2004). Success and Spirituality in the New Business Paradigm. Journal of Management Inquiry, 13(3), 249-260.

Mallillin, L. L. D. (2017). Probable Causes of Absenteeism, Tardiness and Under Time of Employees in Selected Higher Education Institutions: Implications to their Job Performance. International Journal of English Research, 3(2), 42-48.

Mani V. \& Jaisingh S. (2014). A Multivariate Approach to Determine the Drivers of Employee Absenteeism. Australian International Journal of Humanities and Social Studies, 1(1), 14-30.

Martin, J. (1971). Some Aspects of Absence in a Light Engineering Factory. Occup Psychol., 45(2), 77-89.

Martocchio, J.J. (1989). Age-related Differences in Employee absenteeism: A MetaAnalysis. Psychology and Aging, 4(4), 409.

Martocchio, J.J. \& Harrison, D.A. (1993). To be There or not be there?: Questions, Theories, and Methods in Absenteeism research. Research in Personnel and Human Resources Management, 11, 259-328.

Mason, C. M., \& Griffin, M. A. (2003). Group Absenteeism and Positive Affective Tone: A Longitudinal Study. Journal of Organizational Behavior, 24(6), 667-687.

McHugh, M. (2001). Employee Absence: an Impediment to organizational health in local government. International Journal of Public Sector Management, 14(1), 43-58.

McHugh, M. (2002). The absence bug: a treatable viral infection?. Journal of managerial psychology, 17(8), 722-738.

Meneze, M. M. (2005). The Impact of Stress on productivity at Education Training and Development Practices: Sector Education and Training Authority. Pretoria, South Africa: University of Pretoria.

Mets, J., \& LaDou J. (2003). Diagnosis of Absenteeism. Journal of Occupational Medicine. 42, $162-170$.

Metzner, H., \& Mann, F. (1953). Employee Attitudes and Absences. Personnel Psychology, 6(4), 467-485.

Miller, T. I. (1984). The Effects of Employer-sponsored Child Care on Employee Absenteeism, Turnover, Productivity, Recruitment or Job Satisfaction: What is Claimed and What is Known. Personnel psychology, 37(2), 277-289.

MoGA (2011), Governance Bulletin June/July 2011, Ministry of General Administration Kathmandu, 15.

Mohammed J. \& Thyagaraja, C.M. (2013). Employee Absenteeism: A Case Study of Logistics Firms of Hyderabad Karnataka Region. International Journal of Advanced Trends in Computer Science and Engineering, 2(6), 9-11.

Muchinsky, P. M. (1977). Employee Absenteeism: A Review of the Literature. Journal of Vocational Behavior, 10(3), 316-340.

Mugoro, J. (2014). Transport Problems for Students and Their Effects on attendance in Community Secondary Schools in Dar es salaam City, Tanzania (Doctoral dissertation, The Open University of Tanzania). 
Mullins, J. W., \& Forlani, D. (2005). Missing the Boat or Sinking the Boat: A study of New Venture Decision Making. Journal of Business Venturing, 20(1), 47-69.

Nath, T., \& Tanjeen, E. (2014). Factors Influencing Employee Absenteeism: A Study on the Private Commercial Banks in Bangladesh.

Nauta, A., \& Ybema, J. F. (2003). Evaluations Derzoeknaar het Project Introductie Van Mediation in het Onderwijs (IMO). TNO Arbeid, Hoofddorp. 74(3), 368-382.

Navarro, C., \& Bass, C. (2006). The Cost of Employee Absenteeism. Compensation and Benefits Review, 38(6), 26-30.

Naveed, A., Ahmad, U., \& Bushra, F. (2011). Promotion: A Predictor of Job Satisfaction a Study of Glass Industry of Lahore (Pakistan). International Journal of Business and Social Science, 2(16), 43-54.

Nelson, D.L. \& Quick, J.C. (2008). Organizational Behaviour: Foundation, Realities and Challenges, Australia. Thomson South-Western, 34, 115-122.

Ngariand A. (2013). Influence of Employee Relation on Organization Performance. International Journal of Innovative Research and Studies, 2(8), 66-79.

Nicholson, N., \& Goodge, P. M. (1976). The Influence of Social, Organizational and Biographical Factors on Female Absence. Journal of Management Studies, 13(3), 234-254.

Nicholson, N., \& Goodge, P. M. (1976). The Influence of Social, Organizational and Biographical Factors on Female Absence. Journal of Management Studies, 13(3), 234-254.

Nicholson, N., \& Payne, R. (1987). Absence from Work: Explanations and Attributions. Applied Psychology, 36(2), 121-132.

Nicholson, N., Wall, T., \& Lischeron, J. (1977). The Predictability of Absence and Propensity to Leave from Employees' Job Satisfaction and Attitudes Toward influence in DecisionMaking. Human Relations, 30(6), 499-514.

Niedl, K. (1996). Mobbing and well-being: Economic and Personnel Development Implications. European Journal of Work and Organizational Psychology, 5(2), 239-249.

North, F., Syme, S. L., Feeney, A., Head, J., Shipley, M. J., \& Marmot, M. G. (1993). Explaining Socioeconomic Differences in Sickness Absence: the Whitehall II Study. Bmj, 306(6874), 361-366.

Onikoyi, I. A., Awolusia, O. D. \& Ayodeji, B. M. (2015). Effect of Absenteeism on Corporate Performance: A Case Study of Cadbury Nigeria Plc, Ikeja, Lagos State, Nigeria. British. Journal of Marketing Studies, 3(2), 58-71.

Örücü, E. \& Kaplan, E. (2001). Kamuve ÖzelSektör Çalışanlarında Devamsızlık Sorunu. Celal Bayar Üniversitesi İ.̇.B.F Yönetimve Ekonomi Dergisi, 8(1), 93-112.

Pandey, D., \& Joshi, P. R. (2010). Service Quality and Customer Behavioral Intentions: A Study in the Hotel Industry. California Journal of Operations Management, 8(2), 72-81.

Pilbeam, S., \& Corbridge, M. (2002). People Resourcing: HRM in Practice. London: Financial Times.

Piwonski, L. K. (1999). Causes of Absenteeism within the Customer Relations Department of the Oneida Tribe. (Doctoral Dissertation, University of Wisconsin-stout).35(4), 85-94. 
Piwonski, M. A., \& Roosen, A. (1999). Low Pressure Lamination of Ceramic Green Tapes by Gluing at Room Temperature. Journal of the European Ceramic Society, 19(2), 263-270.

Pleck, J.H., Staines, G.L. \& Lang, L. (1980) Conflicts between Work and Family Life, Monthly Labor Review, 103, 29-32.

Prabhat, S. (2016). Factor Affecting Employee Absenteeism in Nepalese Commercial Banks. Nepalese Journal of Finance, 4(1), 66-73.

Price, J. L. (1995). A Role for Demographic Variables in the Study of Absenteeism and Turnover. International Journal of Career Management, 7(5), 26-32.

Adhikari, D., \& Gautam, D. K. (2010). Labor Legislations for Improving Quality of Work Life in Nepal. International Journal of Law and Management, 52(1), 40-53.

Vishwakarma, R.K., Arpit, S. \& Sourabh, N. (2015). Job Satisfaction and Its Impact On Absenteeism: A Case Study Related To Teachers In Private Engineering Colleges. International Journal of Engineering Technology and Management Research, 3(1), 10-15

Rathod, R., \& Reddy, M. B. (2012). Employee Absenteeism: A Study at Titan Industry Limited, Bangalore. Marketing, 43(950), 8-83.

Rentsch, J. R. (1990). Climate and Culture: Interaction and Qualitative Differences in Organizational Meanings. Journal of Applied Psychology, 75(6), 668-681.

Rentsch, J. R., \& Steel, R. P. (2003). What Does Unit-level Absence Mean? Issues for Future unit-level Absence Research. Human Resource Management Review, 13(2), 185-202.

Rhodes, S.R. \& Steers, R.M. (1990), Managing Employee Absenteeism, Addison-Wesley, Reading, Massachusetts.

Rosenblatt, Z., \& Shirom, A. (2005). Predicting Teacher Absenteeism by Personal Background Factors. Journal of Educational Administration, 43(2), 209-225.

Salancik, G. R., \& Pfeffer, J. (1978). A Social Information Processing Approach to Job attitudes and task design. Administrative Science Quarterly, 23, 224-253.

Schneider, B., andReichers, A. E. (1983). On the etiology of climates. Personnel Psychology, 36, 19-39.

Scott, K.D., and Taylor, G. S. (1985). An examination of conflicting findings on the relationship between job satisfaction and absenteeism: A meta-analysis. Academy of Management Journal, 28(3), 599-612.

Shaw, M. E. Group Dynamics. New York: McGraw-Hill, 1976.

Silva, D. M.P.P. da, Marziale, M. H.P. (2000). Absenteísmo de trabalhadores de enfermagemem um hospital universitário. Revista Latino-Americana de Enfermagem, 8 (5), 44-51.

Snipes, R. L., Oswald, S. L., LaTour, M., \& Armenakis, A. A. (2005). The effects of Specific Job Satisfaction Facets on Customer Perceptions of Service Quality: an Employee-level Analysis. Journal of Business Research, 58(10), 1330-1339.

Spector, P.E. (1985). Measurement of Human Service Staff Satisfaction: Development of the Job Satisfaction Survey. American Journal of Community Psychology, 13(6), 693-713.

Stannack, P. (1996). Perspective on Employees' Performance. Management Research News, 119(4), 38-40. 
Steel, R. P. (2003). Methodological and Operational Issues in the Construction of Absence Variables. Human Resource Management Review, 13(2), 243-251.

Steers, R.M. \& Rhodes, S.R. (1978) Major Influences on Employee Attendance: A Process Model, Journal of Applied Psychology, 63(4), 391-407.

Stockford, L. O. (1944). Chronic Absenteeism and Good Attendance. Personnel Journal, 23, 202-207.

Stormer, S., \& Fahr, R. (2013). Individual Determinants of Work Attendance: Evidence on the Role of Personality. Applied Economics, 45(19), 2863-2875.

Taylor, S. (1998). Employee Resourcing. People and Organisations: London, 28(3), 234-343.

Thirulogasundaram, V. P., \& Sahu, P. C. (2014). Job Satisfaction and Absenteeism Interface in Corporate Sector-A study. IOSR Journal of Humanities and Social Science, 19(3), 64-68.

Tiwari, U. (2014). Impact of Absenteeism and Labour Turnover on Organizational Performance at Iti, Nani Allahabad, India. Abhinav National Monthly Refereed Journal of Research in commerce and Management, 34(10), 9-15.

Väänänen, A., Toppinen-Tanner, S., Kalimo, R., Mutanen, P., Vahtera, J., \& Peiró, J. M. (2003). Job Characteristics, Physical and Psychological Symptoms, and Social Support as Antecedents of Sickness Absence Among Men and Women in the Private Industrial Sector. Social science and medicine, 57(5), 807-824.

Yahaya, A., Yahaya, N., Arshad, K., Ismail, J., Jaalam, S., \& Zakariya, Z. (2009). Occupational Stress and its Effects Towards the Organization Management. Journal of Social Sciences, 5(4), 390-397.

Van Tiem, D. M., Moseley, J. L., Dessinger, J. C., \& O' Brien, C. (2002). Performance Improvement Interventions: Enhancing People, Processes, and Organizations Through Performance Technology. Performance Improvement, 41(1), 45-49.

Waters, L. K., \& Roach, D. (1971). Relationship between job Attitudes and Two Forms of Withdrawal from the Work Situation. Journal of Applied Psychology, 55(1), 92.

Weyman, A., Meadows P. \& Buckingham, A. (2013). Extending Working Life, Annex 6: Audit of Research Relating to Impacts on NHS Employees. England: NHS Employers.

Whitaker, S. C. (2001). The Management of Sickness Absence. Occupational and Environmental Medicine, 58(6), 420-424. 